\title{
Exploring Peer Effect on Mathematics Anxiety among Secondary School Students of Sokoto State, Nigeria through Photovoice Approach
}

\author{
Aliyu Garba ${ }^{1^{*}}$, Norulhuda Ismail ${ }^{2}$, Sharifah Osman ${ }^{2}$, Mohd Rustam Mohd Rameli ${ }^{2}$ \\ ${ }^{1}$ Sokoto State University Nigeria, Faculty of Education, Science Education Department, NIGERIA \\ ${ }^{2}$ Universiti Teknologi Malaysia, School of Education, Faculty of Social Science and Humanities, MALAYSIA
}

Received 21 April 2019 • Revised 26 September 2019 • Accepted 26 September 2019

\begin{abstract}
Mathematics anxiety is prevalent in Nigeria where students have a fear of the subject. Much research has been conducted on the level of mathematics anxiety, the differences between the genders, and its relationship with performance. However, little has been done on the factors for mathematics anxiety, and even less on peers' contribution towards mathematics anxiety. The photovoice approach was applied to capture peers' speech and behaviour, which can intensify or minimize mathematics anxiety. The findings revealed that peers' behaviour, such as poor students causing trouble and intelligent students dominating the lesson, and speech, such as using frightening and discouraging statements in the mathematics classroom, has a direct effect on intensifying mathematics anxiety. However, the findings also showed that peer behaviour, such as achievement of peers and group discussions, and speech, such as positive advice, also minimize mathematics anxiety among students. It can be concluded that peers in their day-to-day interaction can have an effect on students' mathematics anxiety.
\end{abstract}

Keywords: mathematics anxiety, photovoice, peer, intensify, minimize

\section{INTRODUCTION}

Anxiety refers to strain, stress, tension, or confusion in an individual's mind and body (Olatunde, 2009). There are many types of anxiety; these include generalized anxiety disorder (GAD), social phobia, panic disorder, agoraphobia, specific phobia, post-traumatic stress disorder (PTSD) and obsessive-compulsive disorder (OCD) (Calmclinic, 2017). Mathematics anxiety is a form of anxiety which can be categorised under specific phobia. It can appear in the early stages of school (Karoll, 2007), and much like other specific phobias, sufferers tend to avoid the subject because it can cause fear and terror (Calmclinic, 2017).

A vast amount of research has been conducted on mathematics anxiety, and it has produced various overlapping definitions (Stoehr, 2017). Mathematics anxiety includes experiencing or feeling tension and fear that interferes with the manipulation of numbers and the solving of mathematical problems in ordinary life and academic circumstances, causing forgetfulness and loss of self-confidence in the individual (Tobias, 1993). It is also has a negative effect on the individual and leads to stress when dealing with mathematical issues (Ashcraft \& Moore, 2009; Beilock at al., 2010; Lindskog, Winman, \& Poom, 2017a). Escalera-Chávez et al. (2017) see mathematics anxiety as a state of anxiety caused by executing a mathematical task, and it is demonstrated by feelings of apprehension, stress, frustration, aversion, worry, and fear.

Based on previous work on this topic, there are three types of symptoms generally connected with mathematics anxiety: physical, emotional, and cognitive symptoms (Whyte \& Anthony, 2012). The physical symptoms can be seen as those symptoms which an individual portrays when affected by mathematics anxiety, such as a nervous stomach, nail biting, difficulty breathing, and sweating. Meanwhile, emotional symptoms are the most dominant

(C) 2020 by the authors; licensee Modestum Ltd., UK. This article is an open access article distributed under the terms and conditions of the Creative Commons Attribution License (http://creativecommons.org/licenses/by/4.0/). $\triangle$ aliyugarba.ag@gmail.com (*Correspondence) $\square$ p-norulhuda@utm.my $\square$ sharifah.o@utm.my 


\section{Contribution of this paper to the literature}

- The symptoms of mathematics anxiety can be divided into physical, emotional, and cognitive symptoms.

- The study uses a qualitative research approach named photovoice to investigate mathematics anxiety.

- The study found that from the students' perspective, peers make a direct contribution to intensifying and minimizing mathematics anxiety.

symptoms of mathematics anxiety; these have to do with inner feelings, such as a lack of confidence, feelings of helplessness, confusion, and exhaustion (Finlayson, 2014); often, a student may just want to leave the lesson and go home due to being stressed about the subject (Finlayson, 2014). Finally, the cognitive symptoms of mathematics anxiety are attributed to mental ability and a predisposition to mathematics, such as the inability to concentrate, negative self-talk, and excessive worrying (Taylor, 2017).

In Nigeria, mathematics is a basic requirement for admission into any science-related subject and technologyoriented course at the tertiary level (Zalmon \& Wonu, 2017). It is a regulation in the Nigerian education system that for admission into university, one must have at least five credit passes in the related course of study inclusive of mathematics and English.

However, Emmanuel et al. (2015) reported the disheartening evidence of the poor performance of students in mathematics examinations at almost every level of education in Nigeria. In their annual reports, the Sokoto state branch of the West African Examination Council (WEAC) indicated that based on the total enrolment for the examination, the students' performance in mathematics at the secondary level recorded $7.12 \%, 7.18 \%, 16.84 \%$, 29.37\% and 31.85\% in 2013, 2014, 2015, 2016, and 2017 respectively (Zalmon \& Wu, 2017). The remaining percentages had fail grades.

Emmanuel et al. (2013) suggested that one of the factors leading to these poor results is the higher level of mathematics anxiety, which affects the students' cognitive and intellectual ability. Arigbabu, Tobih, and Arigbabu (2016) stated that $72.5 \%$ of the total participants in their research in Nigeria had a higher level of mathematics anxiety. In addition, Olatunde (2009) highlighted that $61.5 \%$ of secondary school students in Nigeria had a higher level of mathematics anxiety.

\section{LITERATURE REVIEW}

\section{Many Previous Studies on Mathematics Anxiety have Adopted Quantitative Surveys}

Many studies have been carried out in the area of mathematics anxiety because it remains an important issue of concern in mathematics education. Researchers have used either quantitative, mixed methods, or qualitative approaches when studying mathematics anxiety. However, the quantitative survey design with a large number of respondents appears to be the dominant approach.

Exploratory and descriptive quantitative approaches were used to explore the learners' experience of mathematics anxiety from rural high schools in an academic setting from the students' perspective using a sample of 403 students (Hlalele, 2012). Also, Mutodi and Ngirande (2014) used an exploratory and descriptive quantitative design involving 120 participants to explore the differences in levels of mathematics anxiety in terms of gender, home language, and age.

Kesici (2010) used a descriptive quantitative research design to identify whether middle school learners' mathematics anxiety varies or not in terms of achievement, motivation, and self-esteem. The reading performance, general anxiety, gender difference, and developmental changes in terms of mathematics anxiety in primary and secondary schools were investigated (Hill et al., 2016) using quantitative research with 1,014 students from primary and secondary schools.

A quantitative survey design was utilized to measure achievement and mathematics anxiety with a sample of 195 participants among secondary school students in Malaysia (Zakaria, Zain, Ahmad, \& Erlina, 2012). Furthermore, gender in terms of mathematics anxiety and its relationship to mathematics performance were investigated (Devine, Fawcett, Szúcs, \& Dowker, 2012) using a quantitative survey approach with the sample of 433 secondary school students in Britain.

Similarly, a quantitative cross-sectional field survey design was employed to investigate the mathematics achievement barrier and its relationship with mathematics anxiety in Bruneian secondary school students (Hayati et al., 2013) with 204 participants.

Passolunghi and Mammarella (2016) utilized a descriptive qualitative approach to deal with students' cognitive profile regarding having higher and lower mathematics anxiety. The findings indicate that about 34 students had lower mathematics anxiety and 32 students had higher mathematics anxiety. The two selected groups were tested 
on reading comprehension, reading decoding, and mathematics achievement. In the same vein, Olatunde (2009) conducted a study in some selected secondary schools in Nigeria and employed a descriptive quantitative survey design to investigate the relationship between students' academic achievement and mathematics anxiety.

From the studies highlighted above, it was clear that most of the recent studies on mathematics anxiety applied the quantitative survey approach. They also focused attention on gender and age difference, learners' experiences in terms of mathematics anxiety, measuring the level of anxiety in mathematics, and the relationship between mathematics achievement and mathematics anxiety. However, there is little research that pays attention to the factors that cause mathematics anxiety in the day-to-day interaction in the classroom. Also, little work has been done to explore the interaction among peers, which can exacerbate and intensify mathematics anxiety or reduce and minimize mathematics anxiety among students.

\section{Acquiring Mathematics Anxiety through Social and Environment Interaction}

Although mathematics anxiety could be a response to and a personal feeling of stress when encountering mathematics situations, it could be acquired through observation and interaction with the environment especially in schools and classrooms as a child grows. The interaction with peers as well as teachers could contribute to the development of mathematics anxiety. The overarching theory that supports our view of the development of mathematics anxiety is based on social cognitive theory by Bandura (1986). Social cognitive theory highlights that an individual's learning occurs in social environments by observing other beliefs, attitudes, and skills. People acquire knowledge of societal rules and behaviours be it outside or inside the classroom by observing the modelled behaviour of others and the consequences of the modelled behaviour. Bandura (2001) stated that human behaviour is controlled and shaped automatically and mechanically by environmental factors. Therefore, a negative learning experience of the environment may result in the poor academic performance of the students. According to Stajkovic (2014), in social cognitive theory, "Learning is viewed as knowledge through cognitive processes of information" while according to Bandura (1999), individuals are attributed a self-system that makes them exercise a measure of control over their beliefs, feelings, and actions. The self-system accommodates individuals' cognitive and effective structures, which include the ability to learn from others, imitating others' behaviour, and engaging in selfreflection.

Bandura claimed there are three types of model behaviours, namely, direct, symbolic, and synthesized modelling, and these can be related to how mathematics anxiety proliferates in an individual as a result of observing others.

Direct modelling includes trying to imitate the behaviour of a particular model or live model. Live models include family members, work partners, friends, and others with whom the individual has direct contact. For example, an individual is in direct contact with their social environment, such as friends, teachers, and family members, which results in the individual imitating directly from them some negative behaviours with regard to mathematics. In a class where the majority of the peers have a negative attitude towards mathematics, there is a likelihood of a student who is interacting with such a group to be influenced by this behaviour directly and to also develop a negative attitude towards mathematics. This can be supported by the assertion that "social interaction with the teacher and friends has a direct effect on students' learning"' (Rice et al., 2013).

Symbolic modelling comprises a character displayed on television or in textbooks, as well as anything that is pictorial or animated in nature. In other words, a symbolic model is a pictorial representation of the behaviour of an individual and can be acquired through interaction with whoever displays it in a particular community or environment. For example, having only a depiction of male mathematicians in textbooks may lead female students to assume or perceive mathematics as difficult and meant only for males. This could result in mathematics anxiety because the female students may feel that they are excluded from the processes. According to Gresham (2007) symbolic representation of mathematics concepts has a direct effect on students' performance in mathematics.

Synthesized modeling is concerned with generating behaviour as an effect of a continuous observed act. For instance, the student may learn to hate mathematics by observing teachers' or peers' negative behaviour. For example, the behaviour of a mathematics teacher who is constantly berating his students can result in the students modelling a behaviour which suggests a hate for mathematics, such as being reluctant to participate in class and not completing assignments. Conversely, peers' and teachers' positive behaviour and speech may yield or influence students' interest in mathematics and reduce the level of anxiety in the subject. There is supporting evidence that learners can acquire or develop mathematics anxiety as a result of the negative behaviour of teachers or peers in mathematics (Sian L Beilock \& Willingham, 2014).

As reported by Newman et al. (2017), students generally perceive that their peers are potential helpers in an academic setting. Therefore, this perception can positively or negatively affect students' learning. Spaniol (2017) stated that some students attribute mathematics anxiety to peers' lack of success in mathematics, and thus, the lack of students' success is one of the factors that cause mathematics anxiety. According to Yurt (2014), sharing peers' 
negative experiences about mathematics affects students' success and self-belief in mathematics. From experience, some peers contributed a lot to their counterpart students in developing anxiety not only in mathematics subjects but also in mathematics-related subjects, such as biology, chemistry, geography, and economics. Some will make a discouraging statement, such as "I hate mathematics", "Mathematics is a difficult subject", and "I will never understand mathematics" (Whyte \& Anthony, 2012). Such statements can easily influence their peers' perception that mathematics should be avoided. This is in line with Mutodi and Ngirande (2014), who claimed that mathematics anxiety is a learned behaviour.

An encouraging statement such as "I believe that I will be successful in mathematics" (Yurt, 2014) from peers can boost students' confidence in mathematics (Usher \& Pajares, 2009). Conversely, sharing peers' negative experiences about mathematics affects students' success and self-belief in mathematics (Yurt, 2014). From experience, some peers contribute significantly to their counterpart students developing anxiety not only in mathematics subjects but also in mathematics-related subjects, such as biology, chemistry, geography, and economics. Some will make a discouraging statement such as "I hate math (Whyte \& Anthony, 2012) "mathematics is difficult subject", "I will never understand math"... Such statement can easily influence their counterpart perception that mathematics should be avoided.

Thus, we feel that one of the causes of mathematics anxiety could be from interaction with peers. What peers say and do (their speech and behaviour) in their daily interaction with friends during mathematics classes can have a direct effect on the level and frequency of mathematics anxiety among individual students, where it can either intensify or minimize mathematics anxiety. As mentioned previously, a possible approach to explore this area of research is through photovoice.

\section{Photovoice Approach}

Photovoice is a qualitative research approach for collecting data (Nykiforuk, Vallianatos, \& Nieuwendyk, 2011). It involves a step-by-step process whereby individuals can identify and describe a particular phenomenon (in this case, peers' behaviour and speech, which can intensify and minimize mathematics anxiety) with the help of a specific photograph technique by analysing those photographs with the help of in-depth interview techniques (Wang \& Burris, 1997). Participants are furnished with cameras to take photographs; the images allow the participants to record and demonstrate their strengths and major concerns about the particular phenomenon (Hergenrather et al., 2009). Wang and Burris (1997) stated that the main advantage of photovoice is flexibility; it can be adapted to the various fields of participatory research in any group or community (Arias, 2014). It also serves as a reminder when conducting interviews and shows the sincerity of the research.

Photovoice has been used in a variety of research fields, such as in nutrition (Valera, Gallin, Schuk, \& Davis, 2009) and chronic pain (Baker \& Wang, 2006). The photovoice approach has the potential to be used to uncover behaviours and speech by peers in the classroom that contribute to intensifying mathematics anxiety or minimizing it. Participants can capture events that occur during interaction with peers. They are then able to use these photographs to recall and describe in detail during the one-to-one interviews those events that helped to either intensify or minimize their mathematics anxiety.

\section{PROBLEM STATEMENT}

Mathematics anxiety is a critical issue in the area of mathematics education, and it can seriously affect students' performance. Mathematics education in secondary schools of Sokoto state is aimed at encouraging creativity as well as computational and abstract thinking among the students, but still, according to Ibrahim, Galadima and Yushau (2007), despite the efforts being made by educationists and mathematics teachers toward improving the quality of education in the mathematics subject, student achievement is very poor in Sokoto state. As one of the major problem affecting mathematics classroom in the state, the students' interest is very low; this can be seen from the Sokoto state interim report recommendation on education in Sokoto (2016), which stated that only $11 \%$ of the students have a relevant mathematics textbook and less than $15 \%$ have mathematical items, such as graph boards, compasses, protractors, and geometrical material (solid figure). This can also be seen as a problem which has emerged to affect students' performance in the area. In addition, failure to use appropriate teaching and learning materials has a significant effect in not inspiring students' interest in mathematics education as well as not relating mathematical phenomena to real-life situations.

Most of the research on mathematics anxiety focuses the attention on gender and age difference and on learners' experiences in terms of mathematics anxiety, as well as measuring the level of anxiety in mathematics and the relationship between mathematics achievement and mathematics anxiety using a quantitative approach. However, there is little evidence of an in-depth qualitative approach being used to explore the causes of mathematics anxiety from interaction with peers. The photovoice approach could be used to explore peers' factors in intensifying or 
Table 1. The structured questions for one-to-one interviews

\begin{tabular}{|c|c|c|c|}
\hline & Intensifying mathematics anxiety & & Minimizing mathematics anxiety \\
\hline \multirow[t]{2}{*}{ Introduction } & What can you see here? & \multirow[t]{2}{*}{ Introduction } & What can you see here? \\
\hline & How were you feeling when the picture was taken? & & How were you feeling when the picture was taken? \\
\hline Behaviour & What did your peer do to make you feel that way? & Behaviour & How did the peer's behaviour help you feel that way? \\
\hline Speech & What did your peer say to make you feel that way? & Speech & How did the peer's speech help you feel that way? \\
\hline
\end{tabular}

Table 2. Peer Behaviour that Intensifies Mathematics Anxiety

\begin{tabular}{|c|c|c|c|}
\hline Category & Codes & Example of verbatim & $\begin{array}{l}\text { Percentage of } \\
\text { Responses }\end{array}$ \\
\hline \multirow{4}{*}{$\begin{array}{l}\text { Peer Behaviour } \\
\text { that Intensifies } \\
\text { Mathematics } \\
\text { Anxiety }\end{array}$} & \multirow{2}{*}{$\begin{array}{l}\text { Causing trouble in } \\
\text { the mathematics } \\
\text { classroom }\end{array}$} & $\begin{array}{l}\text { Making noise in maths lesson, which causes the teacher to punish us. I am } \\
\text { scared. }\end{array}$ & \multirow[t]{2}{*}{$6(27.27 \%)$} \\
\hline & & $\begin{array}{l}\text { Playing with one another in the classroom, and our teacher will punish us. I don't } \\
\text { feel good. }\end{array}$ & \\
\hline & $\begin{array}{l}\text { Domination of the } \\
\text { intelligent students }\end{array}$ & $\begin{array}{l}\text { My peer is very good at maths; always when our teacher asks a maths question, } \\
\text { he will quickly say he understands, and our teacher will just go ahead to the next } \\
\text { topic. }\end{array}$ & 1 (4.55\%) \\
\hline & $\begin{array}{l}\text { Less consideration } \\
\text { from peers }\end{array}$ & $\begin{array}{l}\text { My friend is better at maths than I am, but he is arrogant and does not help me. } \\
\text { He can't show me how to do the calculation because I cannot understand }\end{array}$ & 15 (68.18\%) \\
\hline Total & & & 22 (100\%) \\
\hline
\end{tabular}

minimizing mathematics anxiety from the students' perspectives. Therefore, this study aims to explore from the students' perspectives peers' behaviours and speech, which can intensify and minimize mathematics anxiety.

\section{METHODOLOGY}

A total of twenty students with high mathematics anxiety were identified to be participants of this study. The participants were identified using Cognitive Emotional and Physical symptoms Mathematics Anxiety Rating scale (CEP-MAR) with twenty (20) items developed by the researchers, which was adopted from Godbey (1997) using MAS with ten (10) items aims to measure the cognitive, emotional, and physical symptoms of mathematics anxiety. The rating scale was validated by two experts in the Department of Educational Sciences, Mathematics, and MultiMedia and the Department of Educational Foundation and Social Sciences, Universiti Teknologi Malaysia (UTM) for the face validity. The Cronbach alpha score of the instrument was found to be .810 , which is considered acceptable. The ten female and ten male students who were selected had scored the highest for mathematics anxiety in the rating scale distributed to 102 students. In the Nigerian context, the male students are normally separated from the female students, and there is a mixed age range in one classroom. Ten cameras were distributed; each pair of students were given one camera and instructed to capture peers' actions and expressions during class time which they felt either intensified or minimized their mathematics anxiety. The photos were captured in four classroom sessions. After each session, a one-to-one structured interview was conducted where the students were asked to select one photograph for each case (intensify or minimize mathematics anxiety) to discuss. See Table 1 for the structured questions.

The data gathered from the interviews and photos were first transcribed (see Appendix for examples of transcripts and photos) and analysed using the Nvivo software package. The analysis focused on the development of codes that identified speech and behaviours that intensified or minimized mathematics anxiety as well as the physical, emotional, and cognitive symptoms associated with it. The codes developed were checked for reliability among the four authors until agreement was established. The tables in the findings and discussions show the number of frequency of statements from the interviews, which refers to these codes.

\section{FINDINGS AND DISCUSSION}

\section{Peer Intensifying Mathematics Anxiety}

Table 2 highlights the findings regarding peers' factors in intensifying mathematics anxiety in terms of behaviour. Sub-categories that were identified include causing trouble in the mathematics classroom (which can cause the teacher to punish the whole class) (27.27\%); the intelligent students dominating the lesson (by quickly responding to the teachers' questions and dominating the slow learners) (4.55\%); and peers showing less consideration $(68.18 \%)$, such as not being inclusive in group discussions and not encouraging the students to perceive mathematics as a subject that anyone can learn. The data here suggest that peers' poor behaviour in the classroom not only disrupts the learning process; it also affects other students negatively, such as intensifying their 
Table 3. Peer Speech that Intensifies Mathematics Anxiety

\begin{tabular}{|c|c|c|c|}
\hline $\begin{array}{l}\text { Themes / } \\
\text { categories }\end{array}$ & Codes & Example of verbatim & $\begin{array}{l}\text { Percentage of } \\
\text { Responses }\end{array}$ \\
\hline \multirow{4}{*}{$\begin{array}{l}\text { Peer Speech } \\
\text { that Intensify } \\
\text { Mathematics } \\
\text { Anxiety }\end{array}$} & $\begin{array}{l}\text { Embarrassing } \\
\text { Statement }\end{array}$ & $\begin{array}{l}\text { Calling me a doll whenever I ask her to help me and to explain the lesson that I } \\
\text { don't understand. }\end{array}$ & $1(5 \%)$ \\
\hline & Discouraging & Mathematics is a difficult subject that not everybody will understand. & $12(60 \%)$ \\
\hline & Statement & I am just wasting my time concentrating, but I will never understand. & \\
\hline & Terrifying Statement & $\begin{array}{l}\text { There is one mathematics teacher that has gone mad in their area. I feel scared } \\
\text { Maths can cause high blood pressure. }\end{array}$ & 7 (35\%) \\
\hline Total & & & 20 (100\%) \\
\hline
\end{tabular}

Table 4. Symptoms of Mathematics Anxiety

\begin{tabular}{|c|c|c|c|}
\hline $\begin{array}{l}\text { Themes / } \\
\text { categories }\end{array}$ & Codes & Example of verbatim & $\begin{array}{l}\text { Percentage of } \\
\text { Responses }\end{array}$ \\
\hline $\begin{array}{l}\text { Identified } \\
\text { Symptoms }\end{array}$ & $\begin{array}{l}\text { Cognitive } \\
\text { Symptoms }\end{array}$ & $\begin{array}{l}\text { Feel worried. } \\
\text { Thinking, 'When shall I understand mathematics?' }\end{array}$ & $13(30.23 \%)$ \\
\hline \multirow{2}{*}{ Symptoms } & $\begin{array}{l}\text { Emotional } \\
\text { Symptoms }\end{array}$ & $\begin{array}{l}\text { I don't feel at ease. } \\
\text { I feel unhappy. }\end{array}$ & $24(55.82 \%)$ \\
\hline & Physical Symptoms & $\begin{array}{l}\text { I feel very angry, } \\
\text { I am not in a good mood. }\end{array}$ & $6(13.95 \%)$ \\
\hline Total & & & 43 (100\%) \\
\hline
\end{tabular}

anxiety in learning an already difficult subject (Sian \& Willingham, 2014). Negative behaviours of peers in the classroom can be observed by children and can intensify their mathematics anxiety and reduce their interest in the subject.

Behaviour in the classroom constantly influences members of the class not just at the surface level. Instead, it seems to contribute to changes at the fundamental level and has a lasting effect on children and their life long career choices. This suggests strongly that there is a need for pupils to be taught proper behaviour modification and for teachers to employ effective classroom control strategies which support learning.

With regard to peer speech (Table 3), the participants stressed that their peers' speech had a direct influence on the fear they had developed in the subject. Terrifying (35\%), discouraging (60\%), and embarrassing statements $(5 \%)$ were identified to be the major contributors. The terrifying statements include "There is someone who has gone mad because of the number of mathematical formulae he memorized", "Mathematics can easily destroy your brain", "Mathematics can cause high blood pressure" among other statements. Discouraging statements include "You are just wasting your time; you will never understand mathematics" and "Mathematics is a difficult subject that not everybody will understand". The embarrassing statements include "calling me dull". This view was supported by the similar findings that reported that some students make discouraging statements in the mathematics subject, such as "I hate maths", "Don't pretend you are clever enough" and "Mathematics is difficult" (Whyte \& Anthony, 2012). If such a terrifying situation continues to exist, then it can easily persist and take a new direction not only in mathematics education but in mathematics-related disciplines. For instance, in the area of science-related courses, students must have mathematics knowledge in order to understand such an area. If this excessive fear of mathematics continues, it will significantly affect the whole education system in Nigeria, which in the near future, will start experiencing a shortage of mathematics teachers in the state. Students will also tend to avoid mathematics-related fields even though these are crucial for the country's development. It would create a major problem if due to rampant mathematics anxiety in the nation, the country fails to progress and the situation of poor performance in mathematics continues. Many studies have reported that mathematics anxiety has a prolonged impact on performance.

Indeed, mathematics anxiety has consistently been found to hinder an individual's mathematical performance and attitudes toward mathematics including interest and confidence in learning mathematics (Novak \& Tassell, 2017). High mathematics anxiety joined with negative attitudes toward mathematics are usually among the key factors that steer people away from participating in mathematics classes.

As shown in Table 4, the symptoms identified from the peers' intensifying mathematics anxiety with their percentage of responses includes cognitive symptoms $(12.30 \%)$, such as "feeling worried", "deep thinking that causes a headache", "not interested in mathematics lesson", "uninterested and being disturbed". Emotional symptoms (55.82\%) include "not at ease", "not happy", "feel worried", "not feeling good" and so on. And physical symptoms (13.95\%), include "very angry", "very scared", "not in a good mood" and "deeply frustrated". The most dominant type of symptoms is emotional symptoms. 
Table 5. Peer Behaviours that Minimize Mathematics Anxiety

\begin{tabular}{|c|c|c|c|}
\hline $\begin{array}{l}\text { Themes / } \\
\text { categories }\end{array}$ & Codes & Example of the verbatim & $\begin{array}{l}\text { Percentage of } \\
\text { Responses }\end{array}$ \\
\hline \multirow{4}{*}{$\begin{array}{l}\text { Peer Behaviour } \\
\text { that Minimizes } \\
\text { Mathematics } \\
\text { Anxiety }\end{array}$} & $\begin{array}{l}\text { Achievement of } \\
\text { Peers }\end{array}$ & $\begin{array}{l}\text { My friend is scoring high score in mathematics, and my teacher is saying he is } \\
\text { good student, and I feel motivated to be like him }\end{array}$ & $1(5.55 \%)$ \\
\hline & $\begin{array}{l}\text { Peer Group } \\
\text { Discussion }\end{array}$ & $\begin{array}{l}\text { My friend is good at mathematics and he includes me in their group discussion. } \\
\text { If our friends are discussing, I like that because sometimes the discussion makes } \\
\text { me better understand than our teacher's explanation. }\end{array}$ & $3(16.67 \%)$ \\
\hline & $\begin{array}{l}\text { Peer Motivational } \\
\text { Support }\end{array}$ & $\begin{array}{l}\text { My friend is helping me to understand mathematics. } \\
\text { My friend is good and is very interested in the maths classroom and is } \\
\text { encouraging me. }\end{array}$ & 11 (61.11\%) \\
\hline & $\begin{array}{l}\text { Seriousness of the } \\
\text { Peer }\end{array}$ & $\begin{array}{l}\text { He is always serious to learn math and is advising me to be serious. } \\
\text { He is always making an effort in maths lessons because he likes maths, and I am } \\
\text { interested in his seriousness. }\end{array}$ & $3(16.67 \%)$ \\
\hline Total & & & $18(100 \%)$ \\
\hline
\end{tabular}

Table 6. Peer Speech that Minimizes Mathematics Anxiety

\begin{tabular}{llll}
$\begin{array}{l}\text { Themes I } \\
\text { categories }\end{array}$ & Codes & Example of the verbatim & $\begin{array}{l}\text { Percentage of } \\
\text { Responses }\end{array}$ \\
\hline $\begin{array}{l}\text { Peer Speech } \\
\text { that Minimize }\end{array}$ & Positive Advice & I should continue working hard in maths. I feel very motivated. & $6(37.50)$ \\
$\begin{array}{l}\text { Mathematics } \\
\text { Anxiety }\end{array}$ & $\begin{array}{l}\text { I shall forget about our classmates that are not serious and who say bad things } \\
\text { about the mathematics lesson. I feel very motivated. }\end{array}$ & $10(62.50 \%)$ \\
\cline { 2 - 4 } & Positive Support & $\begin{array}{l}\text { My friend is saying mathematics is good for life. I feel smiling and happy. } \\
\text { "Mathematics is simple"; I feel ok and happy }\end{array}$ & $16(100 \%)$ \\
\hline Total & & &
\end{tabular}

\section{Peer Minimizing Mathematics Anxiety}

In terms of the behaviour of peers (Table 5), the findings (codes) with percentage responses include achievement of peers $(5.55 \%)$, peer group discussion $(16.67 \%)$, peer motivational support $(61.11 \%)$, and peers' seriousness (16.67\%). These findings support the research by Cooc and Kim (2016), which stated that if peers are higher achievers and are performing well academically, then the learner associated with these peers may adopt this behaviour. The achievement of the peers is of great importance because it encourages competition among students, and this can motivate a student to develop an interest in the mathematics classroom and reduce the level of mathematics anxiety. Another important factor is motivational support from peers. By implication, if the peer is motivating his friend toward a particular positive behaviour, it is possible that the friend will develop an interest in that behaviour. The peers' seriousness is another contributing factor that can engage the more anxious student to develop an interest in the mathematics classroom; this can be justified by the fact that if the peer is always concentrating on his book and studies, then a friend who is associating with that peer may easily learn such a behaviour and develop an interest in such an area.

With regard to speech (Table 6), the participants highlighted some statements that helped reduce the level of mathematics anxiety from the findings (Table 4). The statements were categorized as positive advice (37.50\%) and positive support $(62.50 \%)$. Positive advice includes statements like "You should forget about our friends that are not serious and say bad things about mathematics", "You should continue working hard in mathematics" and so on. These, according to the participants, are among the positive statements that minimize the level of mathematics anxiety. Positive support includes statements such as "Mathematics is good for life", "Mathematics is simple", and "I am going to make you understand what you don't understand". This is supported by Yurt (2014), who stated that encouraging statements help reduce the level of mathematics anxiety. A peer has a significant role in helping or discouraging the learner. If a peer is hardworking and serious academically, then there is a tendency for the students associating with that peer to imitate and copy that peer's serious and hardworking attitude and vice versa. Therefore, it is necessary for the peers to put extra effort into motivating and encouraging their friends in order to reduce the level of mathematics anxiety they feel. Thus, sharing peers' positive experience about mathematics affects students' success in mathematics (Jackson \& Leffingwell, 1999).

Table 7 shows the identified symptoms, which can be categorised as cognitive, emotional, or physical. They indicate an alleviation from mathematics anxiety as a result of peer behaviour and speech. The responses that identified the symptoms of peers minimizing mathematics anxiety (Table 7) had the following percentages: cognitive symptoms (13.89\%), such as feeling envy of peers' success and the learners' thinking they are going to understand mathematics. Emotional symptoms (75.00\%) include "feeling motivated", "feeling happy", "feeling 
Table 7. Identified Symptoms that Minimize Mathematics Anxiety

\begin{tabular}{llll}
\hline $\begin{array}{l}\text { Themes I } \\
\text { categories }\end{array}$ & Codes & Example of the verbatim & $\begin{array}{l}\text { Percentage of } \\
\text { Responses }\end{array}$ \\
\hline Identified & & Cognitive & Thinking I am going to understand mathematics. \\
Symptoms & Symptoms & I feel eager to learn. & $5(13.89 \%)$ \\
& Emotional & I feel good. & $27(75.00 \%)$ \\
& I fymptoms & I feel very fresh. & $4(11.11 \%)$ \\
\cline { 2 - 3 } & Physical Symptoms & I am smiling. \\
& I feel comfortable. & $36(100 \%)$ \\
\hline Total & & \\
\hline
\end{tabular}

comfortable", and "feeling very fresh". The physical symptoms $(11.11 \%)$ include smiling and being very happy. The three types of symptoms identified in this regard can be seen as minimizing symptoms.

\section{CONCLUSION}

This study has explored how daily interaction with peers can contribute directly to intensify mathematics anxiety and can also play a role to minimize mathematics anxiety among students. This study indicates that there is a need to create a more positive environment regarding students' interaction to reduce behaviour and speech that can intensify mathematics anxiety. It is suggested that peer tutoring programs can be introduced in Nigeria where the higher performing mathematics students can help weaker students. Collaborative learning in which teams of students work together to achieve a common goal can also create a supportive environment where students can encourage each other. Teachers can also encourage peers in minimizing mathematics anxiety using simple classroom activities, such as directing peers to clap when a student gives the correct answer or peers sending short motivational notes to each other to encourage learning mathematics. The interviews conducted with the students explored some factors that would help in minimizing the problem; these include giving quizzes and competitions, creating a conducive learning environment, teachers being mindful of the slow learners, and encouraging the use of intrinsic and extrinsic motivational statements. Peers' achievement, peer group discussions, and motivational and supportive statements have a great impact in minimizing the level of mathematics anxiety.

\section{REFERENCES}

Arias, I. F. Y. (2014). Identification of Safety Challenges Faced by Hispanic Construction Workers Using Photovoice. University of Colorado.

Arigbabu, Tobih, \& Arigbabu. (2016). Assessment of University Undergraduate Students' Mathematics Anxiety and Conception of Mathematics. In Proceedings of the 2nd Interdisciplinary Conference of TASUED-UCC 2016 22 ${ }^{\text {nd }}$ August, 2016 - 25st August, 2016 at Tai Solarin University of Education, Nigeria. Assessment (pp. 1192-1207).

Ashcraft, M. H., \& Moore, A. M. (2009). Mathematics Anxiety and the Affective Drop in Performance. Journal of Psychoeducational Assessment, 27(3), 197-205. https:/ / doi.org/10.1177/0734282908330580

Baker, T. A., \& Wang, C. C. (2006). Photovoice: Use of a participatory action research method to explore the chronic pain experience in older adults. Qualitative Health Research, 16(10), 1405-1413. https:/ / doi.org/10.1177/1049732306294118

Bandura, A. (1986). Social Cognitive Theory of Learning. Social Cognitive Theory. Retrieved from http://info.psu.edu.sa/psu/maths/007SocialCogTheory01.pdf

Bandura, A. (1999). Social cognitive theory of personality. In I. L. P. \& O. J. (Ed.), Ed.). Handbook of personality (2nd ed., pp. 154-196). New York: Guilford Publications.

Bandura, A. (2001). Social Cognitive Theory: An Agentic Perspective. Annu. Rev. Psychol., 52(1), 1-26. https://doi.org/94305-2131

Beilock, S. L., Gunderson, E. A., Ramirez, G., \& Levine, S. C. (2010). Female teachers' math anxiety affects girls' math achievement. Proceedings of the National Academy of Sciences, 107(5), 1860-1863. https:/ / doi.org/10.1073/pnas.0910967107

Beilock, S. L., \& Willingham, D. T. (2014). Math Anxiety : Can Teachers Help Students Reduce It? American Educator, 28-33.

Calmclinic. (2017). The 7 Main Types of Anxiety - The Anxiety Guide. Retrieved October 7, 2017, from https://www.calmclinic.com/anxiety-guide/main-types

Cooc, N., \& Kim, J. S. (2016). Peer influence on children's reading skills: A social network analysis of elementary school classrooms. Journal of Educational Psychology, 109(5), 727-740. https:/ / doi.org/10.1037/edu0000166 
Devine, A., Fawcett, K., Szúcs, D., \& Dowker, A. (2012). Gender differences in mathematics anxiety and the relation to mathematics performance while controlling for test anxiety. Behavioral and Brain Functions, 8(1), 33. https:/ / doi.org/10.1186/1744-9081-8-33

Emmanuel, O., Abonyi, O. S., Abonyi, O. S., \& Omebe, C. (2015). Effects of Problem-Based Learning Approach on Junior Secondary School Students' Achievement in Algebra. Journal of the Science Teachers Association of Nigeria, 50(July).

Emmanuel, O. O., Ngozi, U. P., \& Nwoga, N. A. (2013). Effects of Rational Emotive Behaviour Therapy and Emotional Intelligence on Mathematics Anxiety of in-School Adolescents in Owerri Municipal Nigeria. European Journal of Sustainable Development, 2(3), 85-98. https:/ / doi.org/10.14207/ ejsd.2013.v2n3p85

Escalera-Chávez, M. E., Moreno-García, E., García-Santillán, A., \& Rojas-Kramer, C. A. (2017). Factors that promote anxiety toward math on high school students. Eurasia Journal of Mathematics, Science and Technology Education, 13(1), 189-199. https:/ / doi.org/10.12973/ eurasia.2017.00611a

Finlayson, M. (2014). Addressing math anxiety in the classroom. Improving Schools, 17(1), 99-115. https://doi.org/10.1177/1365480214521457

Godbey, C. (1997). Mathematics Anxiety and the Underprepared Student. Information Center Eric, 52(1), 13-14. https:// doi.org/01990o63

Gresham, G. (2007). A Study of Mathematics Anxiety in Pre-Service Teachers. Early Childhood Education Journal, 35(2). https:/ / doi.org/10.1007/s10643-007-0174-7

Hayati, M., Hamid, S., Shahrill, M., Matzin, R., Mahalle, S., \& Mundia, L. (2013). Barriers to Mathematics Achievement in Brunei Secondary School Students: Insights into the Roles of Mathematics Anxiety, SelfEsteem, Proactive Coping, and Test Stress. International Education Studies, 6(11). https://doi.org/10.5539/ies.v6n11p1

Hergenrather, K. C., Rhodes, S. D., Cowan, C. A., Bardhoshi, G., \& Pula, S. (2009). Photovoice as community-based participatory research: A qualitative review. American Journal of Health Behavior, 33(6), 686-698. https:/ / doi.org/10.5993/AJHB.33.6.6

Hill, F., Mammarella, I. C., Devine, A., Caviola, S., Passolunghi, M. C., \& Szucs, D. (2016). Maths anxiety in primary and secondary school students: Gender differences, developmental changes and anxiety specificity. Learning and Individual Differences, 48, 45-53. https:/ / doi.org/10.1016/j.lindif.2016.02.006

Hlalele, D. (2012). Exploring rural high school learners' experience of mathematics anxiety in academic settings. South African Journal of Education, 32(3), 267-278.

Galadima, I., \& Yushau, M. (2007). An investigation into mathematics performance of senior secondary school students in Sokoto state. Abacus, 32(1), 24-33.

Jackson, C. D., \& Leffingwell, R. J. (1999). The role of instructions in creating math anxiety in students from kindergarten through college. The Mathematics Teacher, 92(7), 583-586. Retrieved from http:/ / search.proquest.com.ezproxyles.flo.org/docview / 204693877?accountid=12060

Karoll, D. (2007). Why is Math So Hard for Some Children? The Nature and Origins of Mathematical Learning Difficulties and Disabilities. Brookes, 29(3), 241. https:// doi.org/10.1097/DBP.0b013e31817aefe8

Kesici, S. E. A. (2010). Mathematics Anxiety According to Middle School Students' Achievement Motivation and Social Comparison. Education, 131(1), 54-63.

Lindskog, M., Winman, A., \& Poom, L. (2017). Individual differences in nonverbal number skills predict math anxiety. Cognition, 159(1), 156-162. https://doi.org/10.1016/j.cognition.2016.11.014

Mutodi, P., \& Ngirande, H. (2014). Exploring Mathematics Anxiety: Mathematics Students' Experiences. Mediterranean Journal of Social Sciences, 5(1), 283-294. https://doi.org/10.5901/mjss.2014.v5n1p283

Newman, R. S., Schwager, M. T., Newman, R. S., \& Schwager, M. T. (2017). Students' Perceptions of the Teacher and Classmates in Relation to Reported Help-Seeking in Math Class. The University of Chicago Press Journal, 94(1), 3-17.

Novak, E., \& Tassell, J. L. (2017). Studying preservice teacher math anxiety and mathematics performance in geometry, word, and non-word problem-solving. Learning and Individual Differences, 54(1), 20-29. https:/ / doi.org/10.1016/j.lindif.2017.01.005

Nykiforuk, C. I. J., Vallianatos, H., \& Nieuwendyk, L. M. (2011). Photovoice as a Method for Revealing Community Perceptions of the Built and Social Environment. International Journal of Qualitative Methods, 10(2), 103-124. https:/ / doi.org/10.1177/160940691101000201

Olatunde, Y. P. (2009). Mathematics Anxiety and Academic Achievements in Some Selected Senior Secondary Schools in Southwestern Nigeria. Pakistan Journal of Social Sciences. 
Passolunghi, M. C., \& Mammarella, I. C. (2016). Mathematics Anxiety, Working Memory, and Mathematics Performance in Secondary-School. Frontiers in Psychology, 7(February), 1-8. https:/ / doi.org/10.3389/fpsyg.2016.00042

Rice, L., Barth, J. M., Guadagno, R. E., Smith, G. P. A., \& Asert, D. M. M. (2013). The Role of Social Support in Students' Perceived Abilities and Attitudes toward Math and Science. Springer Science+Business Media, 10281040. https:/ / doi.org/10.1007/s10964-012-9801-8

Sokoto state. (2016). Sokoto state interim report recommendation on education. sokoto. Retrieved from https:/ / www.slideshare.net/pgfnigeria/sokoto-state-interim-report-recommendations-on-education

Spaniol, S. R. (2017). Students' Mathematics Self-Efficacy, Anxiety, and Course Level at a Community College. ProQuest Dissertations and Theses, $105 . \quad$ Retrieved from https:/ / search.proquest.com/docview/1904509452?accountid=15272

Stajkovic, A. (2014). Social cognitive theory and self- efficacy: Implications for motivation theory and practice. Research Gate, 1(May), 126-140.

Stoehr, K. J. (2017). Mathematics Anxiety. Journal of Teacher Education, 68(1), 69-84. https:/ / doi.org/10.1177/0022487116676316

Taylor, S. R. (2017). Successful Teacher Practices for Reducing Mathematics Anxiety In Secondary Students. CarsonNewman University.

Tobias, S. (1993). Overcoming Math Anxiety. W.W. Norton. Retrieved from https:/ / www.amazon.com/Overcoming-Math-Anxiety-Sheila-Tobias/dp/0393313077

Usher, E. L., \& Pajares, F. (2009). Sources of self-efficacy in mathematics: A validation study. Contemporary Educational Psychology, 34(1), 89-101. https:// doi.org/10.1016/j.cedpsych.2008.09.002

Valera, P., Gallin, J., Schuk, D., \& Davis, N. (2009). “"Trying to Eat Healthy”' A Photovoice Study about Women's Access to Healthy Food in New York City. Journal of Women and Social Work, 24(3), 300-314. https:/ / doi.org/10.1177/0886109909337378

Wang, C., \& Burris, M. A. (1997). Photovoice: Concept, Method, and Use for Participatory Needs Assessment. Health Education E Behavior, 24(3), 369-387.

Whyte, J., \& Anthony, G. (2012). Maths Anxiety: The Fear Factor in the Mathematics Classroom. New Zealand Journal of Teachers' ..., 9(1), 6-15. Retrieved from http://www.teacherswork.ac.nz/journal/volume 9_issue1/whyte.pdf

Yurt, E. (2014). The Predictive Power of Self-Efficacy Sources for Mathematics Achievement, 39(176), 159-169. https://doi.org/10.15390/EB.2014.3443

Zakaria, E., Zain, N. M., Ahmad, N. A., \& Erlina, A. (2012). Mathematics Anxiety and Achievement among Secondary School Students. American Journal of Applied Sciences, 9(11), 1828-1832. https:/ / doi.org/10.3844/ajassp.2012.1828.1832

Zalmon, I. G., \& Wonu, N. (2017). Comparative Analysis of Student Mathematics Achievement in West African Senior Secondary. European Journal of Research and Reflection in Educational Sciences, 5(1), 24-31. 


\section{APPENDIX}

\section{Peer Intensifying Mathematics Anxiety Structured Interview Excerpt}

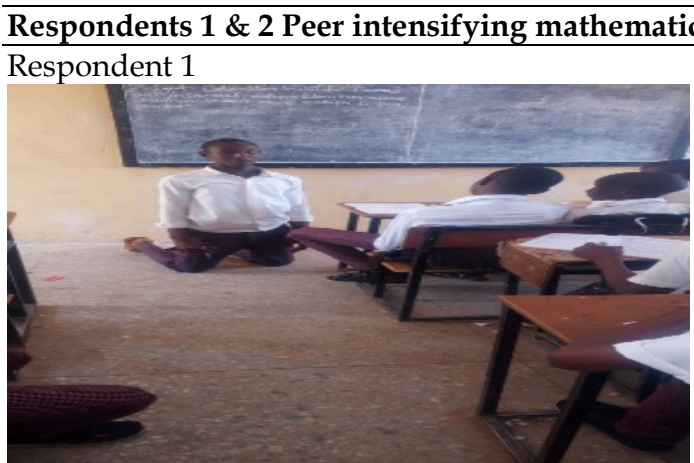

What can you see here?

It is my friend.

How were you feeling when the picture was taken?

I was feeling scared.

What did your peer do to make you feel that way?

He was regularly making noises in the maths lesson because he doesn't like maths, and I am scared in the mathematics lesson because our teacher can punish all of us because of the noise.

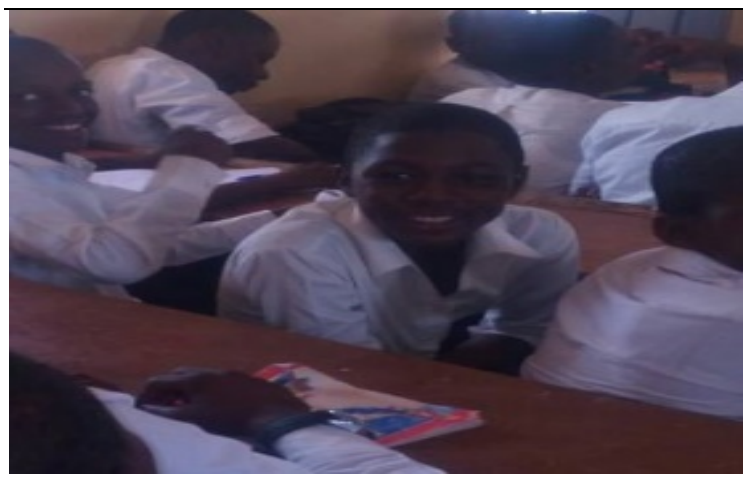

What can you see here?

It is my friend

How were you feeling when the picture was taken? I was feeling scared

What did your peer say to make you feel that way?

My friend said in his area, very close to their home,

somebody told him there is one mathematics teacher who has gone mad because of the number of

formulae he has memorized, and he is calculating on the wall of so many buildings in their area.

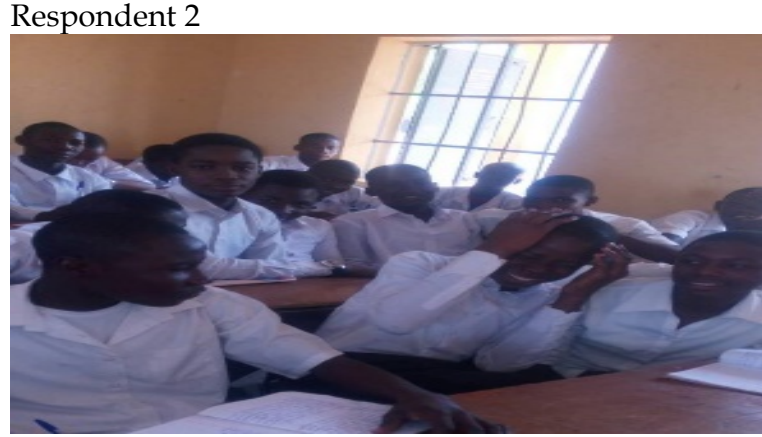

What can you see here?

It is my peer. We are in the same class.

How were you feeling when the picture was taken?

I was not at ease.

What did your peer do to make you feel that way?

He was playing in the classroom because he doesn't have any interest in mathematics, and he was making our teacher angry with us and punish us.

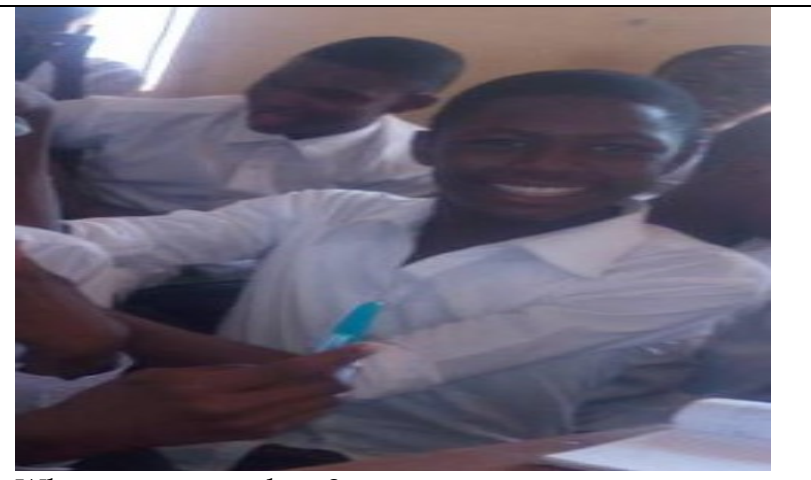

What can you see here?

It is my friend

How were you feeling when the picture was taken? I was not feeling happy.

What did your peer say to make you feel that way?

Most of the time he is saying I am not going to understand mathematics because maths is difficult and not easy to understand and is just calculation on a space that needs very deep thinking. I feel no interest in maths; it is just wasting my time. 


\section{Minimizing Mathematics Anxiety Structured Interview Excerpt}

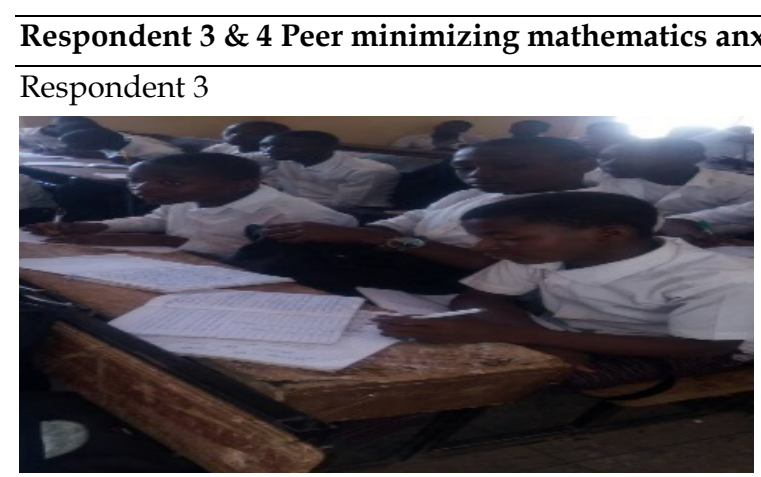

What can you see here?

It is my classmate

I am in the same class with him and he is my good friend and we are in the same area.

How were you feeling when the picture was taken? I felt good and was thinking I am going to understand mathematics.

How did the peer behaviour help you feel that way?

My friend was helping me to understand mathematics. At home, my friend, if he is not busy, I go to his house at the weekend and he teaches me what he understands.

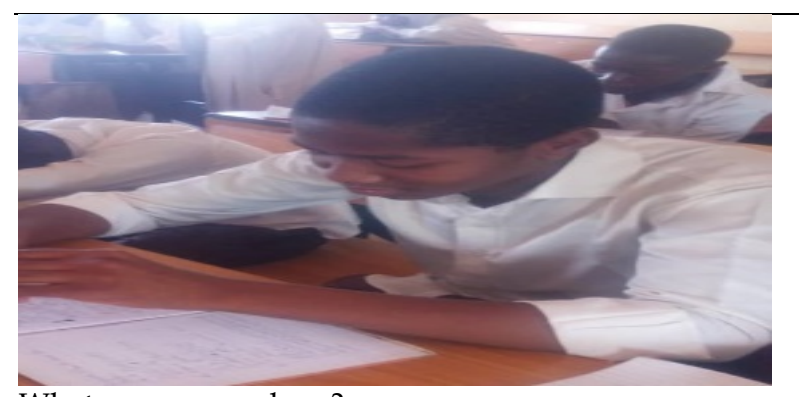

What can you see here?

It is my friend

How were you feeling when the picture was taken? I was feeling very fresh, smiling and happy.

How did the peer's speech help you feel that way? My friend was saying mathematics is good for life, business, and he was saying he was going to make me understand. I feel good.

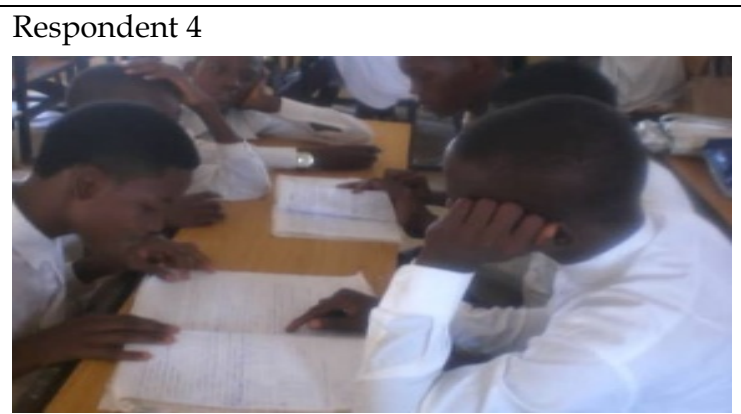

What can you see here?

\section{It's my peer}

How were you feeling when the picture was taken? I was feeling good and happy.

How did the peer behaviour help you feel that way?

My friend is good at mathematics, and he was including me in their group discussion. I felt very happy and interested.

\section{http://www.ejmste.com}

